\title{
Amebic liver abscess with bacterial superinfection in a patient with no epidemiologic risk factors
}

\author{
P. Sánchez-Pobre, S. Saénz-López, E. Salto ${ }^{1}$ R. Sanjuán ${ }^{1}$, C. Ibero² A. Masedo and J. A. Solís Herruzo \\ Department of Medicine. Service of Digestive Diseases. ${ }^{1}$ Department of Microbiology and Service of Infectious \\ Diseases. ${ }^{2}$ Department of Internal Medicine. Hospital Universitario 12 de Octubre. Madrid, Spain
}

\begin{abstract}
The amebic liver abscess is uncommon in developed countries like Spain, but the incidence is increasing probably due to the migratory movements of the population. We report a case of an amebic abscess, initially unsuspected due to the absence of epidemiologic risk factors and the negative serology for amebiasis, in the early stages of the disease.
\end{abstract}

Key words: Amebic liver abscess. Liver abscess. Amebiasis. Entamoeba histolytica.

Sánchez-Pobre P, Saénz-López S, Salto E, Sanjuán R, Ibero $C$, Masedo A, Solís-Herruzo JA. Amebic liver abscess with bacterial superinfection in a patient with no epidemiologic risk factors. A prospective study. Rev Esp Enferm Dig 2004; 96: 796-800.

\section{INTRODUCTION}

The amebic liver abscess (ALA) has a worldwide incidence of 50 cases per year (1). In developing countries like Vietnam, were infection by Entamoeba histolytica is endemic, the annual incidence of amebic liver abscess is 21 cases per 100,000 habitants. In developed countries such as the United States, it is unusual and is most commonly seen in immigrants from and travelers to developing countries (2). It has also been reported in imunosuppressed patients, HIV patients, patients on corticosteroids or suffering from chronic infections like tuberculosis or syphilis and patients who have undergone post-traumatic

Recibido: 12-11-04.

Aceptado: 16-11-04.

Correspondencia: Pilar Sánchez-Pobre. Departamento de Medicina Aparato Digestivo. Hospital Universitario 12 de Octubre. Avda. de Córdoba, s/n. 28041 Madrid. e-mail: psanchezp@meditex.es splenectomy. It has also been associated with acute hepatitis A or B (HBV) $(3,4)$.

Entamoeba histolytica is a protozoa that infects humans by fecal-oral contact. It usually inhabits the colon, where it can cause an asymptomatic infection or it can become invasive and cause amebic colitis. After invasion into the intestinal mucosa, it can disseminate to other organs, predominantly the liver, leading to an amebic abscess.

The epidemiology in Spain is unknown. There are small series of cases and isolated cases described in the literature (5-10). Some of these cases lacked history of exposure and happened in groups at risk or were considered autochthonous, as the case that we report, that developed on the background of hepatitis B surface antigen (HBsAg) carrier, with no other factors associated.

\section{CASE REPORT}

48-year-old man, active cigarette smoker and light drinker. Asymptomatic carrier of hepatitis B surface antigen (HBsAg), with normal liver profile. He denied having travelled abroad or any contact with immigrants from developing countries. He did not take any medication. He was admitted to our hospital with a 5-day history of dull and continuous abdominal pain in epigastrium and mesogastrium, sweating, chills and a temperature of up to $39^{\circ}$ $40^{\circ} \mathrm{C}$. He denied respiratory symptoms or changes in bowel habit. On admission, the temperature was $39^{\circ} \mathrm{C}$, his abdomen was tender in the right upper quadrant, with voluntary guarding but negative Murphy and Blumberg signs. The laboratory investigations revealed leucocytosis of 15,300 leuc/ $\mu 1$ with left shift, with no anemia or thrombocytosis; the erythrocyte sedimentation rate was $93 \mathrm{~mm} / \mathrm{h}$; Other laboratory results were as follows: glucose $145 \mathrm{mgr} / \mathrm{dl}$; creatinine $1 \mathrm{mg} / \mathrm{dl}$; albumin 3,3 gr/dl; bilirubin $1,2 \mathrm{mgr} / \mathrm{dl}$; serum glutamic oxalacetic transami- 
nase $30 \mathrm{UI} / \mathrm{L}$; serum glutamate pyruvate transaminase, 47 $\mathrm{UI} / \mathrm{L}$; gamma glutamyl transferase, $93 \mathrm{UI} / \mathrm{L}$; alkaline phosphatase, $149 \mathrm{UI} / \mathrm{L}$, fibrinogen $1710 \mathrm{mgr} / \mathrm{L}$, prothrombin activity $78 \%$, cephaline time $30 \mathrm{~s}$; HBV serology: positive $\mathrm{HBsAg}$, positive AntiHBe, negative antiHBs, negative AntiHB-core $\operatorname{IgM}$ and positive AntiHB-core IgG; positive PCR for HBV DNA, HBV viral load 2.378.000 copies/ml; negative HCV serology; negative HIV serology; negative serology for Entamoeba histolytica on admission (6 days after clinical presentation); determined by the rapid slide test for the detection of amoebic antibodies in serum (Bicho-Latex r-Amibe, Fumouz); sterile blood cultures, negative stool cultures for bacteria and parasites. Abdominal ultrasonography and computed tomography showed a hypodense collection, 7,5 x $5 \mathrm{~cm}$ in diameter, in segment II of the left lobe of the liver, heterogeneous and with rim enhancement, protruding from the liver surface. There were also radiologic findings of chronic liver disease without portal hypertension (Fig 1).

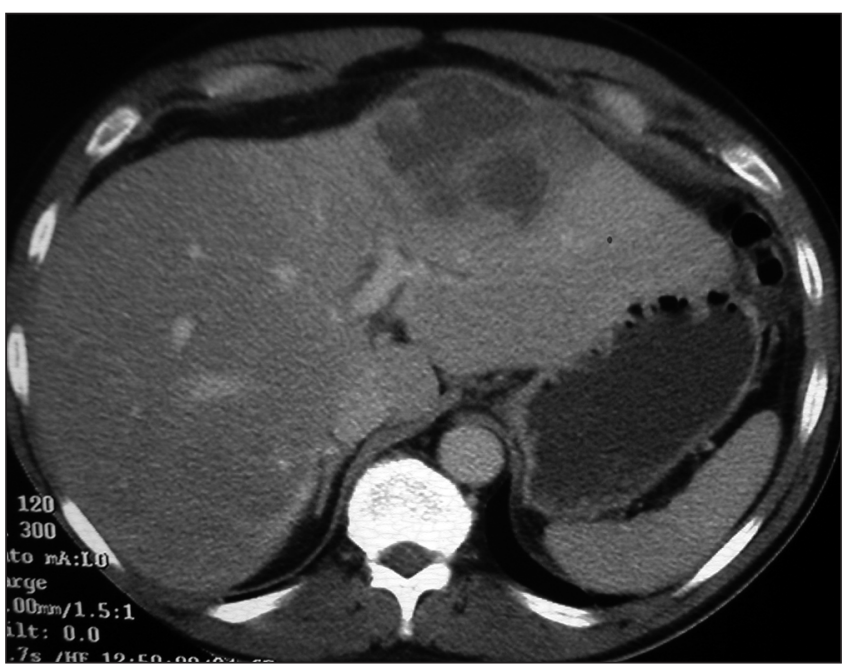

Fig. 1.- The abdominal computed tomography shows a hypodense and heterogeneous collection measuring $7.5 \mathrm{~cm}$ in diameter, with rim enhancement, in segment II of the liver.

Imagen del TAC abdominal, con colección hipodensa de 7,5 cm en segmento II, heterogénea, con realce en su periferia.

A diagnosis of pyogenic abscess was initially entertained, due to the absence of epidemiologic risk factors and the negative serology for Entamoeba histolytica. Antibiotic therapy was initiated with piperaciline-tazobactam and a percutaneous drainage was performed. Aspirate from the abscess was thick in consistency and reddish, "chocolate" coloured, with negative microscopic examination for organisms. A sample of the aspirate was cultured. The abdominal pain improved, but the patient remained with high temperature. The antibiotic regimen was changed to imipenem. The diagnosis of ALA was confirmed after identifying motile forms of Entamoeba histolytica in the liver aspirate, with negative culture for bacteria (Fig. 2). Treatment with metronidazole was initi-

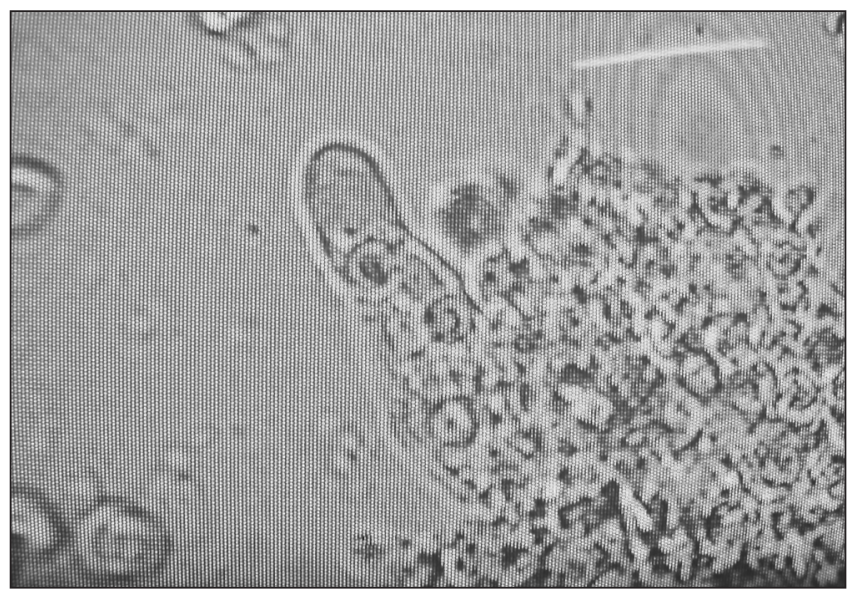

Fig. 2.- E. histolytica trophozoites with ingested erythrocytes found in needle aspiration specimen of liver abscess.

Trofozoitos de E. histolytica con eritrocitos en su interior, extraídos del AHA, por punción percutánea.

ated with disappearance of fever. The patient remained afebrile for 48 hours with subsequent recurrence of the high temperature. A second blood cultures were sterile. Piperaciline-tazobactam was added, with resolution of fever and marked improvement in the patient's condition. There was no need for a second percutaneous drainage. The patient was discharged with levofloxacin for six weeks and radiologic studies obtained one month after discontinuation of antibiotic, showed decrease in the size of the abscess.

\section{DISCUSSION}

The ALA is uncommon in developed countries like Spain in the absence of an epidemiologic history of exposure, such as travelling to endemic countries, contacting with immigrants from regions of endemicity, or belonging to a risk groups. The reported case was an asymptomatic carrier of hepatitis B surface antigen ( $\mathrm{HBsAg}$ ), but had no epidemiologic risk factors for ALA. A case of a HBsAg carrier with simultaneous amebic liver abscess has been reported in an area of endemicity for amebiasis and on the background of hepatitis E infection (11). The case that we describe could be considered an autochthonous case of ALA, related to the increasing number of cases diagnosed in Spain.

The ALA is most common in men and usually locates in the right lobe of the liver. In more than $60 \%$ of cases, like in the case that we describe, the stool examination is negative for parasites. The microbiologic diagnosis is based on the detection of the parasite in the abscess aspirate, although this is an uncommon finding due to the necrotic nature of the abscess (12). The lack of findings consistent with pyogenic abscess (negative gram staining 
and culture) leads to the diagnosis of amebic abscess. Diagnostic percutaneous aspiration is rarely needed. In the case that we report the percutaneous aspiration was required because of false negative serology for amebiasis and the absence of epidemiologic risk factors. Serum tests are usually very helpful in the diagnosis of the disease. Although indirect hemagglutination assay (IHA) is the most sensitive test (90-100\%), the latex agglutination test (13) is rapid and the results correlate with those of IHA, but they can be negative in the first week. The sensitivity increases in the second to third week of the infection. In the present case, the early determination, in the sixth day of the disease, could be the cause of the initial negative result.

The symptoms of ALA are acute and intense in $80 \%$ of cases and consist of epigastric pain and high fever. There is often leukocytosis and abnormal liver profile. The radiological findings are those of a liver abscess and consist of a low density collection on CT or a hypoechogenic lesion on ultrasonography, with posterior acustic shadowing and inner echos that mobilize with postural changes. Nevertheless, there are no pathognomonic findings for ALA (2). Gammagraphy with gallium-67 reveal "cold" lesions with peripheral rim enhancement, unlike in the case of a pyogenic abscess that appear as a capturing lesion. Nevertheless, this technique lacks the specificity that was initially believed (14).

With early diagnosis and treatment, mortality from uncomplicated liver abscess is less than $1 \%$, ranging from $1-34 \%$, and prevents surgery. The complications of ALA are: rupture into the peritoneum, pleural space and pericardium. The risk of rupture is higher in left-lobe abscesses, due to the smaller size of this lobe and the lack of space for a growing mass (2).

The aim of the treatment is to treat invasive liver infection and eradicate colonic colonization. Metronidazole is the drug of choice for the treatment of ALA and amebic colitis (adult dosage of $750 \mathrm{mg}$ orally three times a day for 7-10 days). This therapeutic regimen should be followed by a luminar agent like paramomycin for a period of seven days (2). Most ALA respond to metronidazole therapy. The percutaneous aspiration and drainage of ALA is controversial. Indications for aspiration of liver abscesses are the need to rule out a pyogenic abscess; bacterial coinfection of ALA, large abscesses with a diameter of more than $5 \mathrm{~cm}$, the prevention of rupture of left-lobe abscesses, the failure to respond clinically to drug therapy within 5 to 7 days and the threat of imminent rupture $(2,15,16)$. The percutaneous aspiration can cause the superinfection of the ALA, so it should be avoided in those cases with no indication. This is probably what happened in our case, when the negative serology associated to the absence of epidemiologic risk factors misled to the diagnosis of pyogenic abscess, and subse- quently, an early percutaneous drainage was performed. Surgical treatment should be reserved for instances of rupture of the abscess or coinfection that is not solved with medical treatment $(2,10)$.

The increase of the number of cases in the absence of epidemiologic risk factors in our country, as derived from the increasing number of cases lately reported, and the present case, lead to consider the existence of autochthonous cases. The possibility of ALA should be entertained even in the absence of history of exposure, and serology should be repeated in suspected cases with an initially negative result. An early and accurate diagnosis avoids a higher morbi-mortality, as the treatment for ALA differs from that of the pyogenic abscess. It would be convenient to design epidemiologic studies to know the real prevalence of amebiasis in Spain.

\section{REFERENCES}

1. Ayeh-Kumi PF, Petri WA. Diagnosis and management of amebiasis. Infect Med 2002; 19: 375-82.

2. Rasidul Haque MB, Huston CD, Hughes M, Houpt E, Petri WA. Amebiasis. NEJM 2003; 348:1565-73.

3. Hughes M, Petri W. Amebic liver abscess. Infectious Clinics of North America 2000; 14: 565-82.

4. Amarapurkar DN, Patel N, Amarapurkar AD. Amoebic liver abscess. J Hepatol 2003; 39: 291-6.

5. Garré C, Morán A, Albaladejo A, Garcia J, Mercader J. Absceso hepático amebiano. Rev Esp Enferm Dig 2002; 94: 564-9.

6. Hidalgo ME, Rodríguez JC, Vizoso F, Díez MC. Absceso hepático amebiano de origen autóctono: presentación de un caso. Enferm Infecc Microbiol Clin 2000; 18: 145-6.

7. Lomas JM, Alcoucer R, Saavedra J, Pujol E. Infestación humana por Entamoeba Histolytica. ¿Una enfermedad autóctona de nuestro medio? A propósito de un caso. Rev Clin Esp 2000; 200: 399.

8. Perez E, Cilla G, Urbieta M, Muñoz I. Infeccones autóctonas por Entamoeba Histolytica. Med Clin (Barc) 1985; 85: 254.

9. Rodríguez J, Canut A, Brezmes MF, de Fuentes I. Implicaciones clínico-epidemiológicas de la infección autóctona por Entamoeba Histolytica. Rev Esp Enferm Dig 1995; 87: 835-6.

10. Martín Ezquerro A, González Quijada S, Dueñas Gutiérrez C, Grande Sáez C. Absceso hepático amebiano autóctono. Presentación de un caso. Rev Clin Esp 2004; 204: 43-7.

11. Jain A, Kar P. HBs Ag carrier with simultaneous amebic liver absceso and acute hepatitis E. Ind J Gastroenterol 1999; 55: 179-84.

12. Li E, Stanley SL. Protozoa. Amebiasis. Gastroenterol Clin North Am 1996; 25: 471-92.

13. Robert R, Mahaza C, Bernard C, Buffard C, Senté JM. Evaluation of a new bicolores latex agglutination test for immunological diagnosis of hepatic amebiasis. J Clin Microbiol 1990; 28: 1422-44.

14. Asorey A, Algusacil A, Guerrra JM, Vilalta E. Amebiasis invasiva (II): formas extraintestinales y complicaciones. Diagnóstico parasitológico y serológico. Tratamiento. Rev Esp Enferm Dig 1985; 176: 271-80.

15. Garcia-Forcada A, Sans M, Gascon J, Valls E, Bru C, Corachan M Absceso hepático amebiano: revisión de 13 casos. Med Clin 1995; 105: 537-40.

16. Rendón Unceta P, Macías Rodríguez MA, Correro Aguilar F, et al Abscesos hepáticos: ¿es la punción aspiración simple con control ecográfico una alternativa al drenaje con catéter? Gastroenterol Hepatol 2000; 23: 470-3. 


\title{
Absceso hepático amebiano sobreinfectado sin antecedentes epidemiológicos
}

\author{
P. Sánchez-Pobre, S. Saénz-López, E. Salto ${ }^{1}$, R. Sanjuán ${ }^{1}$, C. Ibero² A. Masedo y J. A. Solís Herruzo \\ Departamento de Medicina de Aparato Digestivo. ${ }^{1}$ Departamento de Microbiología e Infecciosas. ${ }^{2}$ Departamento de \\ Medicina Interna. Hospital Universitario 12 de Octubre. Madrid
}

\section{RESUMEN}

El absceso hepático amebiano es infrecuente en países desarrollados, como lo es el caso de España, pero su incidencia está aumentando, posiblemente en relación con los movimientos migratorios de la población. Presentamos un caso de absceso hepático amebiano, no sospechado inicialmente, debido a la ausencia de antecedentes epidemiológicos y a la negatividad de las pruebas serológicas en las fases iniciales de enfermedad.

Palabras clave: Absceso hepático amebiano. Absceso hepático. Amebiasis. Entamoeba histolytica.

\section{INTRODUCCIÓN}

El absceso hepático amebiano (AHA) tiene una incidencia mundial de 50 millones de infecciones anuales (1). En países en vías de desarrollo como Vietnam, donde es endémica la infección por Entamoeba histolytica, la incidencia anual de AHA es de 21 casos por 100.000 hab. Mientras que en países desarrollados como EE.UU. es infrecuente y habitualmente se detecta en inmigrantes de países en desarrollo o viajeros de esta procedencia (2). También se ha descrito en pacientes inmunosuprimidos; por ejemplo, en infectados por el virus de la inmunodeficiencia humana (VIH), tras el tratamiento corticoideo, infecciones crónicas como la tuberculosis o la sífilis, o tras esplenectomía postraumática, así como también asociado a hepatitis aguda por los virus de la hepatitis A o B (VHB) $(3,4)$.

La Entamoeba histolytica es un protozoo que infecta al hombre por un mecanismo de trasmisión fecal-oral. Habitualmente parasita el colon, donde puede permanecer de forma asintomática o bien invadir y producir una colitis amebiana. Tras la invasión intestinal, puede afectar a otros órganos, principalmente al hígado, donde da lugar a la formación de un absceso amebiano.

La epidemiología del AHA en España es poco conocida. Se han publicado pequeñas series y casos aislados (5-10), alguno de ellos sin que existieran antecedentes epidemiológicos, considerándose en grupos de riesgo o autóctonos, como el caso aquí presentado, cuyo único factor asociado era ser portador del virus de la hepatitis B (VHB).

\section{CASO CLÍNICO}

Varón de 48 años, fumador y bebedor en pequeñas cantidades. Portador del VHB, asintomático y sin alteración de la bioquímica hepática. No refería viajes fuera de España ni contacto con emigrantes. No seguía ningún tratamiento. Ingresó por dolor en epi-mesogastrio sordo, continuo, asociado a fiebre de $39^{\circ}-40{ }^{\circ} \mathrm{C}$, con sudoración y tiritona en los 5 días previos. No presentaba sintomatología respiratoria ni alteración del ritmo intestinal. A la exploración destacaba fiebre de $39^{\circ}$, dolor a la palpación profunda en hipocondrio derecho, con defensa voluntaria pero con signos de Murphy y Blumberg negativos. En la analítica existía leucocitosis de 15.300 leuc/ $\mu$ l con desviación izquierda, sin anemia ni trombocitosis, con una VSG $93 \mathrm{~mm} / \mathrm{h}$; glucosa $145 \mathrm{mg} / \mathrm{dl}$; Creatinina $1 \mathrm{mg} / \mathrm{dl}$; albúmina $3,3 \mathrm{~g} / \mathrm{dl}$; bilirrubina 1,2 mg/dl; GOT 30 UI/L; GPT 47 UI/L; GGT 93 UI/L; FA 149 UI/L. Fibrinógeno $1710 \mathrm{mg} / \mathrm{L}$, actividad de protrombina $78 \%$, TTPA, 30 s. Serología del VHB: HBsAg positivo, antiHBe positivo, antiHBs negativo, antiHB-core IgM negativo y IgG positivo; DNA del VHB por PCR, positivo, carga VHB 2.378.000 copias/ml; serología VHC negativa; HIV negativo. Serología de Entamoeba histolytica, determinada mediante test rápido de detección de anticuerpos frente a E. histolytica (Bicho-Latex r-Amibe, Fumouz), negativa en el momento del ingreso (6 días de inicio del cuadro clínico). Hemocultivos estériles. Coprocultivos y determinación de parásitos en heces negativos. En la ecografía y tomografía axial computarizada (TAC) abdominal se detectó una colección hipodensa de 7,5 x $5 \mathrm{~cm}$ situada en el lóbulo hepático izquierdo, segmento II, heterogénea, con realce en su periferia, que protuía en la superficie hepática. Además, existían signos de hepatopatía crónica sin hipertensión portal (Fig. 1).

A su ingreso, ante la negatividad inicial de la serología para E. histolytica y carecer de antecedes epidemiológicos, se consideró que el enfermo padecía un absceso piógeno. Se trató por ello, con piperacilina-tazobactan y se realizó drenaje percutáneo. Mediante punción, se obtuvó un material espeso-sonrosado achocolatado, donde no se observaban microorganismos y se esperó al cultivo. El dolor abdominal descendió, pero persistió la fiebre elevada, motivo por el que se modificó la pauta de antibióticos a imipenem. 
Se confirmó el diagnóstico de AHA por la detección de formas móviles de Entamoeba histolytica en el líquido drenado del absceso, con cultivo negativo para bacterias (Fig. 2). Por este motivo se instauró tratamiento con metronidazol, tras lo cual el paciente quedó afebril durante 48 horas, en que reapareció nuevamente la fiebre. Mediante nuevo TAC abdominal se descartó que existieran complicaciones locales y se obtuvieron nuevos hemocultivos que fueron también estériles. Se asoció piperazilina-tazobactam con lo que el paciente quedó afebril y siguió una evolución clínica excelente y no precisó nuevo drenaje del absceso. Al alta, se mantuvo con levofloxacino durante 6 semanas y se constató la reducción del tamaño del absceso al mes del cese del tratamiento antibiótico.

\section{DISCUSIÓN}

El AHA es raro en países desarrollados, como España, si no existe un antecedente epidemiológico, por ejemplo, como un viaje a países endémicos, el contacto con emigrantes de estas zonas o la pertenencia a grupos de riesgo. El caso referido carecía de estos antecedentes, excepto el ser portador del VHB. Esta circunstancia se ha descrito en algún caso de AHA, aunque, en general, ello ha ocurrido en países donde la amebiasis es endémica y en el contexto de hepatitis aguda E (11). Por ello, parece que se trate de un caso de AHA autóctono, relacionado con el aumento de casos de AHA que se está observando en España. Esto podría deberse al incremento de la inmigración desde países donde esta infección es endémica.

El AHA es más frecuente en varones y tiende a localizarse en el lóbulo hepático derecho. En más del $60 \%$ de los casos y como ocurrió en nuestro caso, no se detecta el parásito en las heces. El diagnóstico microbiológico se basa en la detección del parásito en el absceso, si bien se trata de un hallazgo poco frecuente debido al carácter necrótico del absceso (12). La ausencia de datos que abogaran por el carácter bacteriano del absceso (gram y cultivo negativos) apoyan la etiología amebiana. Sin embargo, sólo ocasionalmente es precisa la punción del absceso para confirmar esta etiología. En nuestro caso esta punción fue necesaria ya que la serología era falsamente negativa, y el paciente carecía de factores epidemiológicos. La serología es habitualmente muy útil en la confirmación del diagnóstico. Si bien la hemaglutinación indirecta (HAI) es la técnica más sensible, ya que es positiva en el $90-100 \%$ de los casos, las pruebas de aglutinación con látex se correlacionan con la HAI y tienen la ventaja de su rapidez (13), pero pueden ser negativas durante la primera semana. Su sensibilidad aumenta en la segunda a tercera semana de la infección. Posiblemente en nuestro caso la precocidad de la determinación, en el $6^{\circ}$ día de enfermedad, explique su resultado falso negativo.

Las manifestaciones clínicas del AHA son agudas e intensas en el $80 \%$ de los casos y consisten en dolor epigástrico y fiebre elevada. Suele existir leucocitosis y alteración del perfil hepático. Las características radiológicas son las de un absceso hepático, es decir, la de una colección hipodensa en el TAC o hipoecogénica en la ecografía, con refuerzo posterior y ecos finos en su interior que se desplazan con los cambios posturales. No obstante, no existen datos patogneumónicos de su etiología amebiana (2). En la gammagrafía con galio-67, se han descrito como lesiones característicamente frías pero con halo periférico, diferentes a las de los abscesos piógenos, que mostrarían una intensa captación. Sin embargo, estas exploraciones carecen de la especificidad que inicialmente se les atribuyó (14).

Con un diagnóstico y tratamiento precoces, se evita la cirugía y se describe una mortalidad, en los casos no complicados, menor del $1 \%$, pero que oscila entre el 1 y el $34 \%$. Las complicaciones del AHA son: la ruptura de este en la cavidad abdominal, pleura o pericardio. Las probabilidades de ruptura son mayores en los abscesos localizados en el lóbulo hepático izquierdo, debido a su menor tamaño e incapacidad para albergar una masa en expansión (2).

El tratamiento es fundamentalmente médico. Su objetivo es tratar la enfermedad invasiva hepática y erradicar la colonización intestinal. Ello se consigue con la administración de metronidazol durante 7-10 días (750 mg/8 horas en adultos), tanto en la enfermedad invasiva intestinal como en el AHA. Esto debe seguirse de la administración de un agente intraluminal, por ejemplo, de paramomicina, durante otros 7 días (2). La mayoría de los AHA responden este tratamiento. La punción-aspiración del absceso, con colocación o no de drenaje percutáneo, es un tema controvertido. Estaría indicado en las siguientes circunstancias: en casos de duda diagnóstica con el absceso piógeno; absceso amebiano sobreinfectado; lesiones grandes (diámetro superior a $5 \mathrm{~cm}$ ), o localizadas en lóbulo izquierdo por su riesgo de ruptura; ausencia de respuesta al tratamiento médico (tras 5-7 días) o riesgo de ruptura inminente $(2,15,16)$. En ausencia de estas situaciones, debería evitarse su punción con el fin de evitar sobreinfecciones del AHA. Esto es probablemente lo que ocurrió en nuestro caso, pero el resultado negativo de la serología y la ausencia de factores epidemiológicos obligó a pensar en la etiología bacteriana del absceso y por ello a su punción-drenaje temprano. El tratamiento quirúrgico sólo es preciso cuando existen complicaciones, por ejemplo, ruptura o sobreinfección no controlada médicamente $(2,10)$.

El aumento de la incidencia en nuestro país de casos sin antecedentes epidemiológicos, como refleja el aumento de casos publicados recientemente y el actual caso, obliga a pensar en casos autóctonos. Por ello se debe aumentar el índice de sospecha clínica ante abscesos hepáticos aunque no existan antecedentes epidemiológicos y repetir la serología en casos de corta evolución con el fin de evitar los falsos negativos precoces. Con ello se puede lograr un diagnóstico y tratamiento tempranos que contribuirían a evitar una mayor morbimortalidad del AHA, dado a que el enfoque terapéutico respecto del absceso piógeno es diferente. Sería además aconsejable realizar estudios epidemiológicos que permitan conocer con exactitud cúal es la prevalencia real de la amebiasis en España. 